\title{
ABOUT TWO MODELS OF MODERN CHRONOLOGY. TO THE PROBLEM OF HISTORY CHRONOLOGY
}

\author{
T.K. Plyshevskaya, Magnitogorsk, Russian Federation, plish@mail.ru, \\ E.M. Buriyak, Magnitogorsk State Technical University named after G.I. Nosov, \\ Magnitogorsk, Russian Federation, lench81@inbox.ru
}

\begin{abstract}
The problem of the dispute, arising at the turn of the centuries - when a new century or millennium comes - is viewed in the article from mathematical point. Controversy about starting chronology points is related to Anno Domini chronology invention. The fact that some researchers took "zero" year as a starting point and others - the first year, resulted in occurrence of the dispute about the correct choice of modern chronology. Authors deem that the first group of researchers use continuous model of chronology, and the other discreet one. Continuous as well as discreet models are used in modern life in different field of activity.

Keywords: discrete model; continuous model; chronology.
\end{abstract}

There was a dispute in mass media and in academic circles in the end of the 20th century about when the new millennium should be marked by celebration - on the 1st of January, 2000 or on the 1st of January, 2001. Opponents brought different arguments which showed that everybody was right. Professor Smirnov M.A. notes that when Anno Domini Chronology appeared there was no "zero year". According to it, the 1st year A.D. arrived on the 1st of January, which was preceded by the 31st of December B.C. That is why when determining a new second century or millennium we speak not about $200 \mathrm{yr}$ or 2000 yr but about 201 yr or 2001 yr accordingly [1]. Others appeal to many dictionaries' presence and subsequent confusion in dating but not to the absence of the "zero year" in chronology [2-4].

From the mathematical standpoint there are two different models of modern chronology.

It should be noted that the time, as well as other physical quantities, possesses the properties of continuity and discreteness. The property of continuity of the time appears in its duration. We express property of time continuity with the help of such words as "permanently", "all the time" and so on. Continuity in mathematics is associated with a number line, invented by Rene Descartes (Cartesius) (1596-1650) [1]. The number line was used in mathematical researches by Pierre de Fermat (1601-1665), who was R. Descartes' contemporary.

The property of discreteness of the time appears in fixation of points in time. It enables events' dating, time periods' measuring, different time-tables' compilation. Two models of modern chronology are based on these two properties of time (continuity and discreteness).

The discrete model of chronology lies in taking years "apiece" (like apples in a basket). For example, the date of the 20th of December, 1732 means that 1731 years are already in the "time basket" and the 1732nd year will fall into the time basket in 11 days.

The continuity model of chronology relies on Cartesian number line. Let's take 1 year on the right-directional time number line as a unit. The point of 1732 on this time line means that the year of 1732 has already finished, and the point of the 20th of December, 1732 is on the left of 1732 point. 
The dispute about when the new millennium comes - on the 1st of January, 2000 or on the 1st of January, 2001 - comes to the fact that adherents of one point of view take the discrete model of chronology as a base, and others - the continuity model.

History, as a science, has to be measured with the help of time. Any event in history needs to be proved by a date. One of the most remarkable Hellenist history specialists Elias Bickerman noted that "a fact can be considered to be historical if it can be defined not only in area but in time too" [6].

The discrete model of chronology is confirmed in scientific researches on history, in which the chronological method of research is used. The founder of this chronology is the 6th century Roman abbot Dionysius Exiguus (Latin for "Dionysius the Humble"). He was ordered by Johannes P.P. I to create new "Easter tables" according to church requirements - Easter was to be held on the first Sunday after the first spring full moon. Dionysius created not only Easter tables but decided to start chronology Anno Domini. This event's first reference relates to $562 \mathrm{yr}$ A.D. [7], but this model of chronology began being used in Western Europe state/public documents only by the 8th century. The use of modern chronology in Russia dates from 18th century and is related to the decree of Peter the First about shifting chronology since Anno Domini but not since the making of the world [8].

It was reasonable that new chronology had been based on the discrete model because there had been centuries ahead of Cartesian coordinates were invented. As many historians note, there was no "zero year" in modern chronology because a discrete model was used. It cannot be stated that continuous models appeared only in the time of Rene Descartes. Hour dial is an implementation of the continuous model, which was used in sundial in ancient Egypt in second millennium B.C.

We use continuous model more often in modern world. It applies to mathematics as well as to history, and is used by people in their daily life. The reason why continuous model is popular is very simple - people got used precisely to it with time. Nowadays continuous model is used in almost every measuring device.

The discrete and the continuous models are used not only in chronology. Both models are used in tailor's tape, for example. Every tailor's tape is marked with $1 \mathrm{~cm}$ points. But numeric numbering may be different. Some tailor's tapes have numbers placed between points and the first centimeter interval has the number 1. Such tailor's tape is the implementation of the discrete model. Other tapes are marked with numbers placed near points and the number 1 is placed near the first point on the left which completely corresponds to the Cartesian number line.

Method of number marking does not hinder anybody who uses a tailor's tape in his/her work, as well as method of chronology (discrete or continuous).

However, some speculations with series of facts and events are possible in historical science, and then not only chronological research method comes to rescue but the synchronistic, diachronic, retrospective methods too, saving a researcher possible confusion and mistakes. For example, the question "When Khan Batu's Mongol-Tatar invasion to Rus happened?" was an object of last researches. The date of the beginning of Mongol-Tatar's invasion - $1237 \mathrm{yr}$ - would seem to be wide known from school bench, but researchers admit after comparing of all facts and the difference between model of chronology that it was $1236 \mathrm{yr}$ [9]. In the end a little difference resulted in common time shift of the whole historian period in Russian history. And as a consequence many idle 
opinions about historian possible falsification appeared among unenlightened people.

People remember about the difference between the discrete and continuous models only in connection with a forthcoming century finishing and the beginning of a new century celebration. A present-day average Russian citizen solves this question in the Russian manner, celebrating the beginning of a new century twice.

Thus, the dispute about the "correct way" of modern chronology comes to the choice of either discrete or continuous model. And in the end the use of any of these models does not lead to dating mistakes.

Received April 7, 2016

\section{References}

1. Smirnov M.A. When Will the Third Millennium Come? Herald of the Russian Academy of Sciences, 1999, vol. 69, no. 8, pp. 766-768. (in Russian)

2. Ivanova N.P., Tsyb S.V. Methodology of Historical and Chronological Study (Based on the Ancient Russia Chronology). Source, Method, Computer, 1996, pp. 23-46. (in Russian)

3. Kharadze E.K., Sabashvili Sh.A. Once More about the Third Millennium Coming. Herald of the Russian Academy of Sciences, 2000, vol. 70, no. 5, pp. 401-403. (in Russian)

4. Babkin M.A., Galuzo V. N. About Genesis of Years in Russia. Policy and Law, 2010, no. 9, pp. 59-61. (in Russian)

5. Descartes R. Geometry. Moscow, Leningrad, GONTI, 1938. (in Russian)

6. Bickerman E.J. Chronology of the Ancient World. Moscow, Nauka, 1975. (in Russian)

7. Vasheva I.Yu. Eusebius of Caesarea and the Problem of Christian Historiography. Bulletin of the Lobachevsky State University of Nizhni Novgorod. Series: History, 2002, no. 1, pp. 5-12. (in Russian)

8. Russian Empire's Full Collection of Laws Since 1649. Vol. III (1689-1699). St. Peterburg, 1830, pp. 680-681. (in Russian)

9. Tsyb S.V. When Did the Battle on the Kalka-River Take Place. The News of Altai State University, 2009, no. 4, pp. 240-244. (in Russian)

УДК 930.24+510.67

DOI:10.14529/mmp160214

\section{О ДВУХ МОДЕЛЯХ СОВРЕМЕННОГО ЛЕТОСЧИСЛЕНИЯ. К ПРОБЛЕМЕ ХРОНОЛОГИИ ИСТОРИИ}

\section{Т.К. Плышевская, Е.М. Буряк}

В работе с математической точки зрения рассматривается вопрос о споре, возникающем на стыке времен: когда начинается новое тысячелетие или век. Разногласия по поводу временного отсчета связаны с появлением летосчисления от Рождества 
Христова. В связи с тем, что некоторые исследователи приняли за точку отсчета нулевой год, а другие - первый, и возник вопрос о правильности выбора хронологического отсчета. Авторы считают, что первые пользуются непрерывной моделью летосчисления, а вторые - дискретной. В современном мире используются как дискретные, так и непрерывные модели в разных сферах деятельности. Показано, что различия в выборе начала отсчета очередного столетия сводятся к различиям в непрерывной и дискретной математических моделях.

Ключевые слова: дискретная модель; линейная модель; летосчисление; хронологический метод исследования.

\section{Литература}

1. Смирнов, М.А. Когда наступит третье тысячелетие? / М.А. Смирнов // Вестник РАН. 1999. - Т. 69 , № 8. - C. $766-768$.

2. Цыб, С.В. Методика историко-хронологического исследования (на примере древнерусской хронологии) / С.В. Цыб // Источник, метод, компьютер. - Барнаул: АГУ, 1996. C. $23-46$.

3. Харадзе, Е.К. Еще раз о начале третьего тысячелетия / Е.К. Харадзе, Ш.А. Сабашвили // Вестник РАН. - 2000. - Т. 70, № 5. - С. 401-403.

4. Бабкин, М.А. О генезисе летоисчисления в России / М.А. Бабкин, В.Н. Галузо // Закон и право. - 2010. - № 9. - С. 59-61.

5. Декарт, Р. Геометрия / Р. Декарт. - М.; Л.: ГОНТИ, 1938.

6. Бикерман, А. Хронология древнего мира: Ближний Восток и античность / А. Бикреман. - М.: Наука, 1975.

7. Ващеева, И.Ю. Евсевий Кесарийский и проблема христианской историографии / И.Ю. Ващеева //Вестник Нижегородского университета им. Н.И. Лобачевского. Серия: История. - 2002. - Вып. 1. - С. 5-12.

8. Полное собрание законов Российской империи с 1649 года. Т. III (1689-1699 гг.). - СПб., 1830. - № 1735 . - С. $680-681$.

9. Цыб, С.В. Когда была битва на Калке / С.В. Цыб // Известия Алтайского гос. ун-та. 2009.- № 4. - C. 240-244.

Татьяна Константиновна Плышевская, кандидат физико-математических наук, доцент, (г. Магнитогорск, Российская Федерация), plish@mail.ru.

Елена Михайловна Буряк, кандидат исторических наук, доцент кафедры истории России, Магнитогорский государственный технический университет им. Г.И. Носова. (г. Магнитогорск, Российская Федерация), lench81@inbox.ru.

Поступила в редакиию 7 апреля 2016 г. 